\title{
IDENTIFIKASI PEMAHAMAN UMUM AYAM (Gallus gallus) DAN IKAN MUJAIR (Oreochromis Mossambicus) PADA MAHASISWA UIN WALISONGO SEMARANG
}

\author{
Bunga Ihda Norra ${ }^{1)}$, Tasya Putri Hendrika ${ }^{2)}$, Ati Auliyaur Rohmah ${ }^{3)}$, Ila Nabinya ${ }^{4)}$ \\ ${ }^{1,2), 3), 4)}$ Program Studi Pendidikan Biologi, Universitas Islam Negeri Walisongo \\ email ${ }^{l)}$ : bungaihda@walisongo.ac.id \\ email $^{2)}$ : tasyaputri_1908086002@student.walisongo.ac.id \\ email $^{3)}$ : atiauliyaur_1908086029@student.walisongo.ac.id \\ email ${ }^{4}$ : ilan8_1908086025@student.walisongo.ac.id
}

\begin{abstract}
ABSTRAK: Konsumsi pangan dapat dilakukan untuk memenuhi kebutuhan gizi di dalam tubuh. Kandungan dalam panganan yang diperlukan tubuh salah satunya yaitu protein. Protein terdiri atas protein nabati dan hewani. Ayam dan ikan mujaer merupakan contoh bahan pangan yang sering ditemui, dan termasuk protein hewani. Tujuan dari penelitian ini yaitu untuk mengetahui pemahaman umum mahasiswa UIN Walisongo terhadap ayam dan ikan mujair. Metode yang digunakan dalam penelitian ini adalah survei dengan menggunakan kuesioner, yang mana responden berasal dari mahasiswa UIN Walisongo Semarang. Ayam dan ikan mujair memiliki banyak manfaat, yang oleh karenanya dapat dijadikan bahan pangan yang kaya akan gizi. Ayam dan ikan mujair mudah ditemukan. Orang-orang sudah tidak asing dengan kedua bahan pangan tersebut. Sama halnya dengan mahasiswa UIN Walisongo yang pastinya sudah tidak asing. Dari penelitian ini dapat diketahui bahwa pemahaman umum mahasiswa UIN Walisongo Semarang terhadap ayam dan ikan mujair sudah cukup paham. Hanya saja, butuh pendalaman materi untuk menguatkan pemahaman.
\end{abstract}

Kata kunci: Pemahaman mahasiswa, manfaat ayam dan ikan mujaer, konsumsi ayam dan ikan mujair

ABSTRACT: Food consumption can be done to meet the nutritional needs of the body. One of the ingredients in the food that the body needs is protein. Protein consists of vegetable and animal protein. Chicken and tilapia fish are examples of food ingredients that are often encountered, and include animal protein. The purpose of this study was to determine the general understanding of UIN Walisongo students towards chicken and tilapia fish. The method used in this research is a survey using a questionnaire, in which the respondents come from students of UIN Walisongo Semarang. Chicken and tilapia fish have many benefits, which are why they can be used as food that is rich in nutrients. Tilapia fish and chicken are easy to find. People are familiar with these two foods. The same is the case with UIN Walisongo students who are certainly familiar. From this research, it can be seen that the general understanding of UIN Walisongo Semarang students towards chicken and tilapia fish is quite understanding. It's just that, it takes a deepening of the material to strengthen understanding.

Keywords: Students' understanding, the benefits of tilapia fish and chicken, consumption of tilapia fish and chicken

\section{PENDAHULUAN}

Konsumsi pangan dapat dilakukan untuk memenuhi kebutuhan zat gizi di dalam tubuh. Zat gizi berfungsi sebagai sumber tenaga bagi tubuh, mengatur proses metabolisme dalam tubuh, memperbaiki jaringan tubuh serta pertumbuhan. Pemilihan bahan pangan dan jumlah makanan dapat dipengaruhi oleh pengetahuan gizi, yang mana dapat 
mempengaruhi status gizi secara tidak langsung dan acuan dalam menentukan makanan yang dikonsumsi (Khomsan, 2000 dalam Soraya et al., 2017)

Bahan makanan hewani merupakan sumber protein yang baik, dalam jumlah maupun mutu, seperti telur, susu, daging, unggas, ikan, dan kerang. Sumber protein nabati adalah kacang kedelai dan hasil olahannya seperti tempe dan tahu, serta kacang-kacangan lainnya. Protein hewani pada umumnya mempunyai kualitas (nilai gizi) lebih tinggi dibandingkan dengan protein nabati. Namun, campuran beberapa bahan makanan sumber protein nabati dapat menghasilkan komposisi asam amino yang secara keseluruhannya mempunyai kualitas cukup tinggi (Diana, 2009).

Dari segi aspek mutu gizi, karena kandungan asam amino esensial yang tidak lengkap pada protein nabati, maka sangat tergantung pada protein nabati. Makanan nabati biasanya mengalami defisiensi beberapa asam amino, yaitu lisin, treonin, triptofan, sistin, dan metionin. Hal ini menjadi masalah karena ketidaklengkapan asam amino esensial dalam makanan dapat menyebabkan daya cerna dan rendahnya pemanfaatan protein yang dikonsumsi (Muhilal et al., 1993).

Pola konsumsi ikan di Indonesia menunjukkan bahwa belum semua rumah tangga mengkonsumsi ikan. Ikan air laut segar merupakan ikan yang paling banyak dikonsumsi rumah tangga. Hasil estimasi model permintaan ikan menunjukkan hampir semua koefisien dianggap berpengaruh nyata dengan koefisien determinasi sebesar 27,06\%. Pada permintaan ikan air laut semua variabel berpengaruh nyata. Pada model permintaan ikan air tawar/payau semua variable tak bebas berpengaruh nyata kecuali faktor pendidikan istri dan pengeluaran ikan (Arthatiani \& Kusnadi, 2018).

Ayam dan ikan mujair adalah bahan pangan yang sering ditemukan, baik di pasar, swalayan, dan rumah makan. Ayam dan ikan mujair menjadi contoh dari bahan makanan yang mengandung protein di dalamnya. Untuk itu, tujuan dari penelitian ini yaitu untuk mengetahui pemahaman umum mahasiswa UIN Walisongo terhadap ayam dan ikan mujaer.

\section{METODE PENELITIAN}

Metode yang digunakan dalam penelitian ini adalah survei. Investigasi adalah melakukan penelitian dengan cara mengumpulkan informasi dari sampel suatu populasi, Tujuannya adalah untuk meringkas ruang lingkup sampel secara keseluruhan dan sampai mana sampel tersebut diambil (Paturochman, 2012). Dalam survei, informasinya berasal dari responden mahasiswa UIN WALISONGO SEMARANG dengan menggunakan kuesioner.

\section{HASIL DAN PEMBAHASAN}

Hasil penelitian berdasarkan survei tingkat kepemahaman mahasiswa UIN Walisongo yang terdiri dari 44 responden yang berasal dari perwakilan delapan fakultas, meliputi Ushuluddin dan Humaniora, Fakultas Sains dan Teknologi, Ekonomi dan Bisnis, Fakultas Hukum dan Syariah, Ilmu Tarbiyah dan Keguruan, Dakwah dan Komunikasi, Ilmu Sosial dan Politik, serta Psikologi Kesehatan. Adapun hasil penelitian sesuai surveynya sebagai berikut:

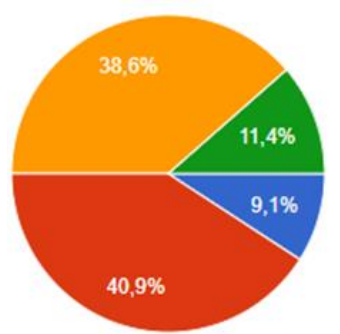

belum paham - sedikit paham paham paham sangat

Survei pengetahuan umum terhadap mahasiswa biologi dan non biologi menunjukkan 40,9\% mahasiswa sedikit paham terkait materi ayam dan mujair, $38,6 \%$ mahasiwa sudah paham, $11,4 \%$ paham sekali dan $9,1 \%$ belum paham. Dalam kasus pada survei ini meskipun 
mahasiswa tersebut bukan berasal dari prodi biologi juga membutuhkan sekilas informasi umum terkait ayam dan mujair, karena pada dasarnya ayam dan mujair merupakan salah satu hewan yang lekat dengan kehidupan manusia.

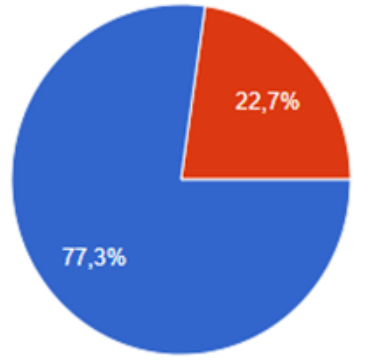

belum sudah

Dari survei terkait pengetahuan nama ilmiah ayam adalah Gallus gallus, dimana menunjukkan Sebagian mahasiswa belum mengetahui nama ilmiah tersebut, hal tersebut sesuai survei yang menyatakan 77,3 belum mengetahui nama ilmiah ayam dan $22,7 \%$ yang sudah mengetahui, dan yang sudah mengetahui merupakan mahasiswa berbasis prodi biologi. Pada dasarnya mata pelajaran yang menjelaskan nama ilmiah merupakan pelajaran berbasis sains, salah satunya biologi yang lebih memperinci pada animalia.

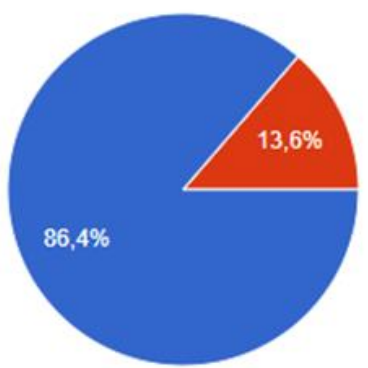

belum

sudah

Berdasarkan data survei diatas menunjukkan bahwa 86,4\% mahasiswa belum mengetahu nama ilmiah mujair adalah Oreochromia mossambicus dan $13,6 \%$ yang sudah mengetahui, dan yang sudah mengetahui merupakan mahasiswa berbasis prodi biologi. Pada dasarnya mata pelajaran yang menjelaskan nama ilmiah merupakan pelajaran berbasis sains, salah satunya biologi yang lebih memperinci pada animalia.

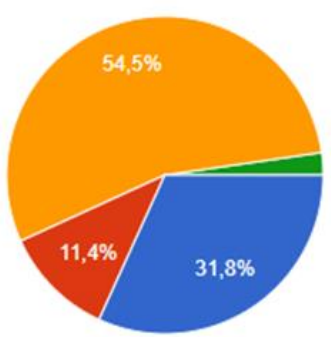

- belum paham sudah paham sedikit paham paham sekali

Dari data survei diatas menunjukkan $54,5 \%$ mahasiswa sedikit memahami karakyter morfologi, anatomi dna fisiologi mujair. $31,8 \%$ belum paham dan $11,3 \%$ sudah paham, dan sisanya paham sekali. Pada dasarnya pengetahuan morfologi merupakan pengetahuan umum yang bisa diamati dari bagian luarnya, meskipun bukan berbasis biologi mahasiswa juga harus memiliki pengetahuan umum terkait kepekaan ilmu di sekitarnya. Sedangkan dari anatomi dan fisiologi merupakan bahasan kompleks yang lebih diperdalam dalam materi biologi. Sehingga dalam kasus ini masih membutuhkan peningkatan pemahaman dasar pada mahasiswa.

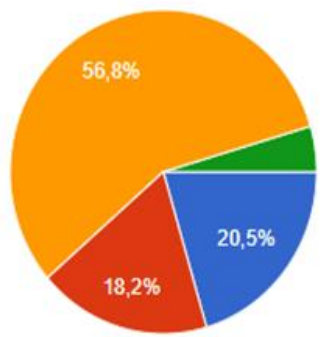

belum paham

sudah paham

sedikit paham

Dalam survei ini menunjukkan pengetahuan mahasiswa terhadap karakteristik morfologi, anatomi dan fisiologi ayam dimana 56,8\% menunjukkansedikit paham, 18,2\% sudah paham, 20,5\% belum paham dan sisanya paham sekali. Pada dasarnya pengetahuan morfologi merupakan pengetahuan umum yang bisa diamati dari bagian luarnya, meskipun bukan berbasis biologi mahasiswa juga harus memiliki pengetahuan umum terkait kepekaan ilmu di sekitarnya. Sedangkan dari anatomi dan fisiologi merupakan bahasan kompleks yang lebih diperdalam dalam materi biologi. Sehingga dalam kasus ini masih membutuhkan peningkatan pemahaman dasar pada mahasiswa. 


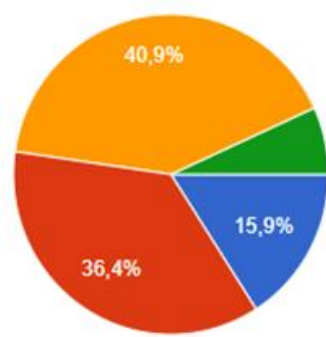

belum paham

sudah paham

sedikit paham

- paham sekali

Dalam survei tersebut dapat diamati $40,9 \%$ mahasiswa telah memahami protein yang terkandung dalam ayam, 36,4\% sudah paham dan $15,9 \%$ belum paham dan sisanya paham sekali. Berdasarkan survei tersebut mahasiswa hanya membutuhkan penegasan atau pengetahuan terkait pemahaman dasar ilmu umum zoologi tersebut.

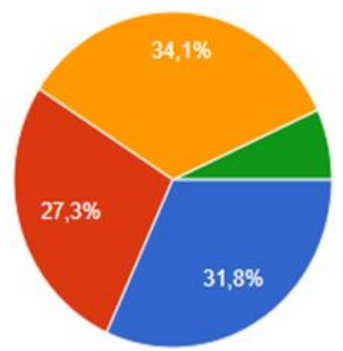

belum paham

- sudah paham

sedikit paham

paham sekali

Dalam survei tersebut dapat diamati $27,3 \%$ mahasiswa telah memahami protein yang terkandung dalam mujair, $34,1 \%$ sedikit paham dan $31,8 \%$ belum paham dan sisanya paham sekali. Berdasarkan survei tersebut mahasiswa masih membutuhkan peningkatan pengetahuan umum terkait mujair.

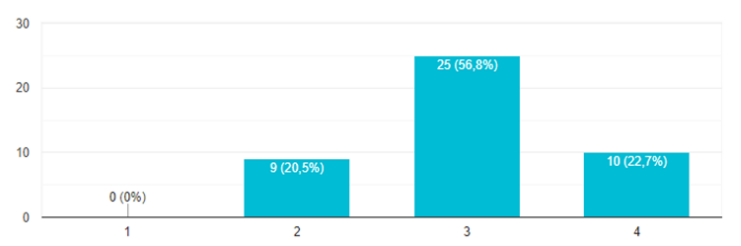

Survei tingkat gizi dari mujair menurut para mahasiswa, data tertinggi pada 56, $8 \%$ yang menyatakan gizi pada mujair cukup tinggi, pada dasarnya mujair memang memiliki protein dan omega yang tinggi.

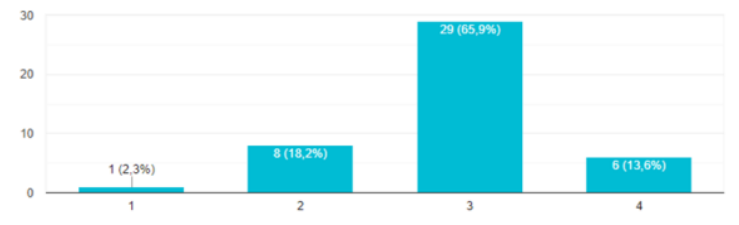

Pada survei diatas menunjukkan menunjukkan $65,9 \%$ yang merupakan presentase tertinggi dimana mahasiswa berpendapat kandungan gizi pada ayam cukup tinggi sehingga banyak diminati untuk dikonsumsi.

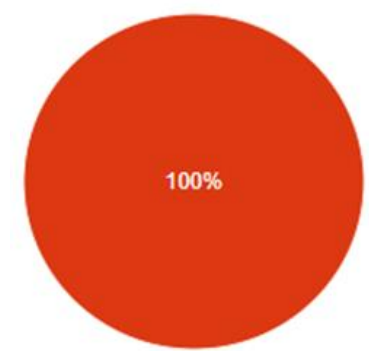

ayam mujair

Dari diagram survei diatas menunjukkan seluruh respondem memahami karakteristik umum yang disajikan terkait mujair. Sebenarnya para mahasiswa sudah memiliki bekal pengetahuan dasar yang cukup tinggi, hanya saja seperti dalam survei sebelumnya mahasiswa masih membutuhkan penguatan ilmu pengetahuan tersebut.

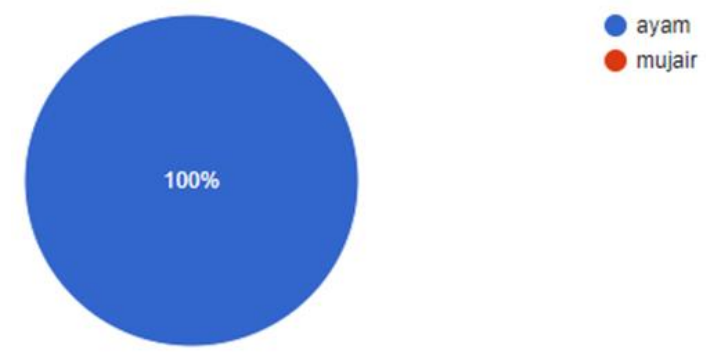

Dari diagram survei diatas menunjukkan seluruh respondem memahami karakteristik umum yang disajikan terkait mujair. Sebenarnya para mahasiswa sudah memiliki bekal pengetahuan dasar yang cukup tinggi, hanya saja seperti dalam survei sebelumnya mahasiswa masih membutuhkan penguatan ilmu pengetahuan tersebut.

Umumnya pengetahuan gizi orang yang diwawancarai dapat diperoleh dari pendidikan formal, keluarga, dan berbagai sumber informasi lainnya (seperti media cetak dan elektronik untuk memperkaya pengetahuan). Pengalaman dan informasi yang diperoleh tentang ilmu gizi juga dapat menjadi pedoman bagi mahasiswa untuk mengaplikasikannya dalam kehidupan 
sehari-hari. Suhardjono

(1989)

mengemukakan bahwa pengetahuan umum serta pengetahuan gizi dan kesehatan akan mempengaruhi komposisi dan cara konsumsi pangan.

Keanekaragaman hayati adalah salah satu sumber daya alam Indonesia. Pengelolaan keanekaragaman hayati dapat menjadi salah satu sumber kesejahteraan masyarakat di Indonesia. Keanekaragaman ini terutama disebabkan oleh adaptasi hewan terhadap habitat dan perilaku alaminya. Dalam unggas misalnya, khusus pada spesies ayam banyak terdapat varietas yang berbeda-beda seperti ayam pelung, ayam cemani, ayam kampung dan ayam broiler. Perbedaan antar subspesies adalah pada anatomi organ respirasi, organ pencernaan, morfologi bulu, otot, dan tulang (Suhai et al., 2006).

\section{Ayam}

$\begin{array}{ll}\text { Kingdom } & \text { : Animalia } \\ \text { Sub-kingdom } & \text { : Metazoa } \\ \text { Phylum } & : \text { Chordata } \\ \text { Sub-phylum } & \text { : Vertebrata } \\ \text { Divisi } & : \text { Carinathae } \\ \text { Kelas } & : \text { Aves } \\ \text { Ordo } & \text { : Galliformes } \\ \text { Family } & : \text { Phasianidae } \\ \text { Genus } & : \text { Gallus } \\ \text { Spesies } & : \text { Gallus gallus domesticus }\end{array}$

Tipe ayam ras petelur ada dua, yaitu tipe ringan dan tipe sedang. Ayam tipe ringan khusus dikembangkan untuk bertelur saja. Ada dua jenis telur pemijahan, yaitu kering dan sedang. Ayam dikembangkan khusus untuk bertelur. Ciri-ciri tersebut adalah ramping, kecil, mata berkilau dan hinggap darah merah. Telur ayam jenis ini harus dijaga agar ukurannya relatif kecil dibandingkan dengan ayam yang berukuran sedang. Ayam ukuran sedang dikembangkan untuk menghasilkan telur dan diambil dagingnya agar bobot dagingnya lebih berat daripada ayam bobot ringan (Rasyaf, 1994).
Ayam merupakan salah satu keanekaragaman hayati yang memiliki peran signifikan dalam mempertahankan keberlanjutan ekosistem. Selain untuk memenuhi kebutuhan protein keluarga, ayam lokal juga dapat membantu perekonomian masyarakat pedesaan, dan biasanya menggunakan kotoran ayam sebagai pupuk tanaman (Soemarwoto, 1985)

Ayam banyak mengandung vitamin B6 yang diperlukan untuk memetabolisme karbohidrat, lemak dan protein, memproduksi sel darah merah, serta memperkuat sistem kekebalan tubuh. Vitamin B3 juga ditemukan dalam daging ayam sekitar $72 \%$ dari total kebutuhan harian tubuh. Vitamin ini diperlukan untuk metabolisme makanan, mengambil energi dari makanan, dan menjaga fungsi sistem pencernaan, kulit dan saraf. Ayam juga terdapat asam amino esensial. Hal ini juga sumber zinc, yang digunakan tubuh dalam pembentukan hormon. Dalam daging ayam menyediakan hampir $40 \%$ selenium dari total kebutuhan harian tubuh. Selain selenium, daging ayam juga menyediakan cukup fosfor bagi pertumbuhan, termasuk perbaikan dan perawatan jaringan otot. Fosfor dalam daging ayam yang besar bisa memenuhi hampir 36\% dari total kebutuhan harian. Fosfor dan vitamin B6 secara bersama-sama bisa memfasilitasi fungsi ginjal dan sistem saraf. Kalium yang sangat dibutuhkan oleh tubuh juga terkandung dalam daging ayam, yaitu 4 ons mengandung sekitar 300 miligram kalium (Erlita, 2015).

\section{Ikan Mujair}

$\begin{array}{ll}\text { Kingdom } & \text { : Animalia } \\ \text { Filum } & \text { : Chordata } \\ \text { Kelas } & \text { : Actinopterygii } \\ \text { Ordo } & \text { : Perciformes } \\ \text { Famili } & \text { : Cichlidae } \\ \text { Genus } & \text { : Oreochromis } \\ \text { Spesies } & \text { : Oreochromis mossambicus }\end{array}$


Ikan mujair adalah sejenis ikan air tawar, pipih, berwarna abu-abu, coklat atau hitam. Badan mujair bertubuh pipih dan ramping, bersisik kecil bertipe stenoid, badan vertikal dan sirip ekor berwarna merah. Warna ikan ini tergantung pada lingkungan atau habitat tempat tinggalnya (Webb et al., 2007).

Ikan mujair diartikan sebagai komoditas perikanan air tawar. Ikan mujair mudah hidup dan berkembang biak dalam berbagai kondisi, seperti kondisi salinitas tinggi dan salinitas rendah. Dibandingkan dengan jenis ikan air tawar lainnya, ikan mujair berkembang biak relatif lebih cepat, sehingga mendukung pasokan ikan mujair secara komersial. Pasokan ikan mujair yang besar dan nilai gizi yang tinggi mendorong masyarakat untuk memilih ikan mujair dan mengolahnya menjadi berbagai macam makanan (Mukrie, 1990).

Ikan mujair dibedakan menjadi beberapa jenis, antara lain mujair biasa, mujair merah, dan mujair albino. Menurut warna sisiknya, ikan ini dapat dibedakan menjadi empat jenis yaitu ikan mujair sisik abu-abu, abu-abu bercak putih, putih-hitam dan merah (Sugiarti, 1988).

Ciri khas ikan mujair adalah rahang yang menguning, yang biasanya terlihat lebih jelas pada ikan jantan dewasa. Panjang tubuh ikan ini 2 sampai 3 kali tinggi badannya (Setianto, 2012).

Ciri yang perlu diperhatikan untuk membedakan induk jantan dan betina adalah betina memiliki tiga lubang pada organ urogenitalnya yaitu rektum, bukan sel telur dan lubang urin. Ujung sirip berwarna merah muda, bagian perut lebih putih, dan dagu berwarna putih, jika perut ditekan tidak akan mengeluarkan cairan (Erika, 2008).

Nilai gizi protein bergantung pada kandungan dan daya cerna asam amino esensial. Daya cerna akan menentukan ketersediaan hayati dari asam amino ini. Proses pengolahan tidak hanya meningkatkan daya cerna protein, tetapi juga menurunkan nilai gizinya. Kebutuhan protein setiap orang adalah $1 \mathrm{~g} / \mathrm{kg}$ berat badan, seperempatnya harus berasal dari protein hewani, dan salah satunya berasal dari daging (Muchtadi, 1989).

Sebagai salah satu sumber protein hewani yang memenuhi kebutuhan masyarakat Indonesia, ikan memiliki banyak keunggulan. Keunggulan ikan sebagai sumber protein hewani adalah kandungan proteinnya berkisar antara $15 \%$ sampai $24 \%$, dan kualitasnya tinggi yang ditunjukkan dengan integritas dan daya cerna asam amino esensial mencapai $95 \%$ (Rahayu et al., 1992).

Heruwati (2002) menunjukkan bahwa ikan dianggap sebagai makanan fungsional yang memiliki arti penting bagi kesehatan karena mengandung asam lemak tak jenuh rantai panjang (terutama yang diklasifikasikan sebagai asam lemak omega $3)$.

Ikan dikatakan lebih sehat dari protein hewani lainnya adalah sebagai berikut: mengandung protein berkualitas tinggi dan kandungan lemak jenuhnya rendah, dengan kadar protein kasar 16-27 per 100 gram. Mengandung asam lemak omega 3, 6 dan 9 yang sangat tinggi, yang merupakan sumber vitamin dan mineral yang sangat tinggi, mengandung asam amino esensial, dan memiliki kandungan lemak yang lebih rendah dibandingkan ayam. Selain itu, kabarnya ada beberapa hal yang istimewa pada kepiting, kerang dan tiram. Dalam kategori produk ini, terdapat zat taurin yang mendorong perkembangan sel saraf bayi melalui ASI (Lestari, 2020).

Ikan mujair juga dapat menggantikan ikan laut, karena kita semua tahu bahwa ikan laut semakin mahal harganya (Erika, 2008). Menurut penelitian Setianto (2012) kandungan gizi ikan yang tinggi sangat bermanfaat untuk kesehatan. Juga telah dibuktikan bahwa konsumsi ikan secara terus menerus dapat menghambat penyakit jantung. Menurut ahli gizi, mengkonsumsi 30 gram ikan sehari dapat mengurangi risiko kematian akibat penyakit jantung 
hingga sebanyak 50\%. Alasan rendahnya tingkat konsumsi ikan di Indonesia adalah sebagai berikut: 1). Masyarakat kurang memahami gizi dan manfaat ikan bagi kesehatan dan kecerdasan, 2). Minimnya pasokan ikan disebabkan belum lancar distribusi, 3). Teknologi pengolahan dan / atau pengawetan ikan belum dikembangkan untuk memenuhi kebutuhan rasa dari semua konsumen dalam bentuk yang beragam; 4) Fasilitas pemasaran, dengan distribusi kualitas dan kuantitas yang terbatas (Lestari, 2020).

\section{KESIMPULAN}

Ayam dan ikan mujair memiliki banyak manfaat, yang oleh karenanya dapat dijadikan bahan pangan yang kaya akan gizi. Ayam dan ikan mujair mudah ditemukan. Orang-orang sudah tidak asing dengan kedua bahan pangan tersebut. Sama halnya dengan mahasiswa UIN Walisongo yang pastinya sudah tidak asing. Dari penelitian ini dapat diketahui bahwa pemahaman umum mahasiswa UIN Walisongo Semarang terhadap ayam dan ikan mujair sudah cukup paham. Hanya saja, butuh pendalaman materi untuk menguatkan pemahaman.

\section{DAFTAR PUSTAKA}

Arthatiani, F. Y., \& Kusnadi, N. (2018). Analisis Pola Konsumsi Dan Model Permintaan Ikan Menurut Karakteristik Rumah Tangga Di Indonesia Analysis of Fish Consumption Patterns and Fish Demand Model Based on Household ' s Characteristics in Indonesia. Jurnal Sosek KP, 13(021), 73-86.

Diana, F. M. (2009). Fungsi dan Metabolisme Protein dalam Tubuh Manusia. Jurnal Kesehatan Masyarakat, 4(1), 49.

Erika, Y. (2008). Gambaran diferensiasi leukosit pada ikan mujair (Oreochromis mossambicus) di daerah ciampea bogor. Institute Pertanian Bogor. Fakultas Kedokteran hewan.

Erlita, Y. (2015). Kandungan Gizi dan Manfaat daging ayam bagi kesehatan. Sumbarprov.Go.Id.

https://sumbarprov.go.id/home/news/5

293-kandungan-gizi-dan-manfaatdaging-ayam-bagi-kesehatan.html

Heruwati, E. S. (2002). Pengolahan ikan secara tradisional: Prospek dan peluang pengembangan. Jurnal Litbang Pertanian, 21(3), 92-99.

Khomsan, A. (2000). Teknik Pengukuran Pengetahuan Gizi. Institute Pertanian Bogor.

Lestari, R. (2020). Pengembangan Media Pembelajaran Spesimen Vertebrata Dan Invertebrata Untuk SMA Negeri 2 Rambah Hilir. Bio-Lectura , 7(1), 3642.

https://doi.org/10.31849/bl.v7i1.4005

Muchtadi, D. (1989). Evaluasi Nilai Gizi Pangan. Pusat Antar Universitas Pangan dan Gizi. IPB.

Muhilal, J., Idrus, H., Jalal, F., \& Tarwotjo. (1993). Angka Kecukupan Gizi yang Dianjurkan. Lembaga Ilmu LPengetahuan Indonesia.

Mukrie, A. N. (1990). Manajemen Pelayanan Gizi Institusi Dasar. Departemen Kesehatan RI.

Paturochman, M. (2012). Penentuan Jumlah dan Teknik Pengambilan Sampel (Untuk Penelitian Sosial Ekonomi). UNPAD Press.

Rahayu, W. P., Slamet, M., Suliantari, \& Srikandi, F. (1992). Teknologi fermentasi produk perikanan. Departemen Pendidikan dan Kebudayaan, Direktorat Jenderal 
Pendidikan Tinggi, Pusat Antar Universitas Pangan dan Gizi, Institut Pertanian Bogor.

Rasyaf, M. (1994). Beternak Ayam Pedaging. Penebar Swadaya.

Setianto, D. (2012). Budidaya Ikan Mujair di Berbagai Media Pemeliharaan. Pustaka Baru Press.

Soemarwoto, O. (1985). Constancy and change in agroecosystems. In: Hutterer KL, Rambo AT, Lovelace G (eds). Cultural Values and Human Ecology. The University of Michigan Center for South and Southeast Asian Studies.

Soraya, D., Sukandar, D., \& Sinaga, T. (2017). Hubungan pengetahuan gizi, tingkat kecukupan zat gizi, dan aktivitas fisik dengan status gizi pada guru SMP. Jurnal Gizi Indonesia (The Indonesian Journal of Nutrition), 6(1), 29-36.

https://doi.org/10.14710/jgi.6.1.29-36

Sugiarti. (1988). Teknik Pembenihan Ikan Mujair dan Nila. Penerbitan CV Simpleks (Anggota IKAPI).

Suhai, B., Gasparik, M., Csorba, G., Gerics, B., \& Hovath., G. (2006). Wall thickness of gas and marrow-filled and tibiotarsi in Crows (Corvus coronecornix) and Magpies (Pica pica). Journal Biochem, 39(2140).

Suhardjono. (1989). Sosio Budaya Gizi. Institute Pertanian Bogor.

Webb, A., Maughan, M., \& Knott., M. (2007). Pest fish profiles Oreochromis mossambicus - Mozambique tilapia. ACTFR, James Cook University. 